\title{
Jews enemies of Christianity?
}

\section{Book Title:}

Presumed guilty: How the Jews were blamed for the death of Jesus

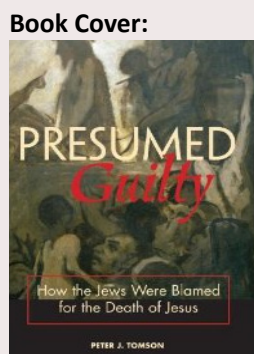

Author:

Peter J. Tomson

ISBN:

0800637070

Publisher:

Fortress, Minneapolis, 2005,

Xiv + p. 146, \$9.99*

*Book price at time of Review

-

Review Title:

Jews enemies of

Christianity?

Reviewer:

Ernest van Eck ${ }^{1}$

Affiliation:

${ }^{1}$ Department of New

Testament Studies,

University of Pretoria,

South Africa

Email:

ernest.vaneck@up.ac.za

Postal address:

Department of New

Testament Studies, Faculty

of Theology, University of

Pretoria, Pretoria 0002,

South Africa

How to cite this book

review:

Van Eck, E., 2011, 'Jews

enemies of Christianity?',

HTS Teologiese Studies/

Theological Studies 67(3),

Art. \#1130, 2 pages.

doi:10.4102/hts.v67i3.1130

(C) 2011. The Authors.

Licensee: AOSIS

OpenJournals. This work

is licensed under the

Creative Commons

Attribution License.
How did it come about that the Jews were blamed for the death of Jesus? How is it possible that the Jews are, by definition, seen as enemies of the gospel and Christians as the enemies of the Jews, if one takes into consideration that the oldest Christian creeds are composed of Jewish concepts and beliefs? What does the Jesus movement have to do with the Jews? And Jesus, the Jew? How were the Jews made into enemies of Christianity? Where should we look for the roots of anti-Semitism? These are the questions Tomson addresses in Presumed guilty: How the Jews were blamed for the death of Jesus (which is a more succinct edition of his book "If this is from heaven ...": Jesus and the New Testament authors in their relationship to Judaism, Sheffield Academic Press, 2001).

Tomson answers the aforementioned questions in two ways. In chapter one he gives a short answer, and in chapters 2-8 the longer answer features. The short answer (chapter 1 ) is as follows: it all began with Jesus, a Jewish man. Many Jews believed in him as the promised Messiah. Others were not so sure. There were others who thought he was dangerous. This last group was successful in letting the Romans get rid of him. Jesus' death, however, was not the end. His disciples took over his tasks. They preached the gospel of Jesus throughout the Jewish homeland, also to non-Jews living there. Jesus' followers also brought the good news to other countries as well (Syria, Asia Minor, Greece and Italy). Everywhere, churches emerged, congregations of Jesus that resembled synagogues. These churches not only read from Moses but also retold the deeds and words of Jesus as his disciples remembered them. In many synagogues, disagreement arose on this topic. During the 1940s and 1950s the members of many of the congregations of Jesus began to refer to themselves as Christians. Soon, all Jesus' followers, both Jews and non-Jews, were thus designated. Up to this point, the different churches had consisted of both Jews and non-Jews. This combination, at times, caused difficulties. Some Jews were afraid that non-Jews would never be totally free of idolatry as long as they had not converted fully to Judaism. Whilst eating together, the Jews would thus be implicated in idolatry. On the other hand, some non-Jews were impatient with Jewish dietary regulations. Mutual distrust set in, and the blame for it cannot be entirely apportioned to either the non-Jews or the Jews. For a large part, the political whirlpool left in the wake of the Jewish War in 66-70 CE is to be blamed. The War put all relationships on the edge, including that between the Jews and the non-Jews in the churches of Jesus. Both in the Jewish homeland, and elsewhere, violence between Jews and non-Jews broke out. After the War, Jews and non-Jews no longer trusted one another. It was at that point that the churches and synagogues went their separate ways. In the synagogues, especially in the Jewish homeland, followers of Jesus were excluded from the community. On the other hand, the churches of Jesus started to consist solely of non-Jews, and the term 'Christian' became synonymous with 'non-Jew'. During the second and third centuries mainstream Christianity became an exclusive non-Jewish movement. From the side of the churches Judaism came to be viewed as the major rival. Consciousness about the church's Jewish origin was repressed, and anti-Jewish thinking emerged within the church.

How does Tomson arrive at the above depiction of the (current) relationship between Christians and Jews? This is discussed in his 'longer answer' (chapters 2-8). As a starting point in unravelling this relationship, Tomson argues that a positive relationship between the 'real' (historical) Jesus and Judaism must be assumed, and one has to distinguish between the question of Jesus and the case against the Jews within the New Testament. The base for this distinction lies in the historical sources in which the reality of Jesus' time is recorded. In this regard the ancient Jewish sources should receive priority (Qumran, the rabbinic literature, Hellenistic-Jewish writings and other ancient Jewish texts, such as 1 Enoch). Other sources to be used include Thomas, Q and the synoptic Gospels (chapter 2). Also necessary for this distinction is a consistent picture of the world of Judaism within the Roman Empire (that portrays the Judaism of that time as diversified).

Turning to Jesus (chapter 4), Tomson is of the opinion that Jesus initially belonged to the reform movement of John the Baptist. Jesus preached 'the gospel of God' that involved repentance (that was a common theme in Jewish prayers of that time). As such, Jesus' movement was a reform movement within Judaism, and Jesus (as a Jew) kept the Jewish law in his own manner. With regard 
to divorce, for example, Jesus' interpretation concurred with that of Qumran, and was stricter than that of the Pharisees. Jesus saw himself as the Son of Man whenever he spoke of the reason for his coming and destiny - a thought adopted and developed by Jesus himself. Jesus had a positive attitude towards the temple, and was concerned about its purity. In this regard, Jesus viewed himself as a prophet who must die in Jerusalem. This is why Jesus foretold his own death and predicted the destruction of the temple. He also saw his death as a self-sacrifice for his followers.

Turning to Jesus' trial (chapter 5), Tomson regards Mark's report as historically the most authentic. Jesus' death was brought on by the Sadducees. The Pharisees were not present at either the trial or the execution of Jesus - an execution mourned by Jesus' disciples and many other people. With regard to the other Gospels (and in a certain sense also Mark), Tomson argues that one must remember that all the biblical Gospels were written for non-Jewish Christians during or after the Jewish War. Because of the War, nonJewish Christians distanced themselves from the Jews and sought the favor of the Romans. This explains why in most sources it is so that with regard to Jesus' trial the Romans are exonerated and the blame is shifted to the Jews.

The fact that it was indeed the Sadducees who had brought on the death of Jesus is attested by the testimony of Jesus' earliest followers (the apostles) after his death (chapter 6). According to Jesus' disciples, his death was part of a series of murders of prophets. They proclaimed (to Jews and later also to non-Jews) that Jesus' resurrection meant that the future had already begun and that God's kingdom would soon come. Very important to note is that this understanding of Jesus' resurrection by the disciples, was informed by their rereading of the Scriptures (Old Testament). As such, the most ancient Christology is composed of elements from Judaism. As a result of the disciples' proclamation, various 'Jewish churches'(apostolic churches) were established (e.g., that of Peter and James). These churches differed from the various synagogues only in their view of Jesus (Christology). This Jewish belief in Jesus was the basis of all later Christianity. Paul's churches, on the other hand, consisted of both Jews and non-Jews - at least eventually. 'Johannine churches' also arose (those who adopted the gospel of John). In the end, because of the War and growing mistrust in the Pauline churches between Jews and non-Jews, the apostolic church won out. By the 2nd century, because of a growing antiJewish theology, the apostolic churches, however, were fully separated from Judaism.

From the above it is clear that, according to Tomson, the church gradually changed her attitude towards the Jews, and an anti-Jewish reading of the Christian gospel gradually developed. The New Testament contains evidence of this development. In chapter 8 Tomson discusses the different New Testament writings, highlighting the anti-Jewish reworking of certain material in the different documents of the New Testament. According to his analysis, an anti-Jewish attitude reveals itself in John and Matthew, and can also be recognised in a few instances in Mark. Mathew, however, contains explicit Jewish-Christian material. Luke and Acts describe the spread of the gospel amongst non-Jews on the basis of continuity with Judaism. The letters of James, Jude and Hebrews, as well as Revelation, are fully JewishChristian. This also applies to the Pauline letters (except for 1 Tt 2:14).

Many historical Jesus-scholars will disagree with Tomson's construction of the 'real Jesus'. The contention that all the Gospels were written for non-Jewish audiences can also be questioned. Tomson also underplays the role the crowd played in the decision to execute Jesus. These few points of criticism, however, do not detract from the fact that Tomson has written a book that is worth reading. His description of the historical circumstances and development of an antiJewish theology in the church that resulted in the current rift between Jews and Christians is excellent. Tomson also reiterates the fact that Jesus was a Jew (the focus of the Renewed Quest or Third Questers), and alerts the reader to the Jewish roots of Christianity. As such, this book can be seen as an effort to bridge the ever increasing rift between Jews and Christians. Scholars interested in the inter-religious debate should take time to read this book. 